\title{
Classical Methods of Chemical Stability - Comparison of Analyses for Gunpowders
}

\author{
Rakić Magdalena ${ }^{1)}$ \\ Krstović Mirjana ${ }^{1)}$ \\ Dimić Mirjana ${ }^{1)}$ \\ Fidanovski Bojana 1)
}

\begin{abstract}
The main ingredient of gunpowder is nitrocellulose. For slowing down the catalytical decomposition process, predominated stabilizer diphenylamine is in use for single-base gunpowder, as well as for propellants. On the other hand, the stabilizer wears out over time, which causes changes in chemical stability of energetic materials. One of the classical methods for determination the chemical stability is the Bergman-Jung method, which has two subgroups. This paper presents comparative analyses for twelve NC and five NCD gunpowder. Namely, both subgroups are based on the calculation of the volume of nitric oxide gases, but the difference between them depend on the method of collecting and determining released gases.
\end{abstract}

Key words: Chemical stability, single-base gunpowder, the Bergman-Jung method, the Schulze-Timan method, Volumetric method.

\section{Introduction}

$\mathrm{D}$ URING the first half of the nineteenth century, an enormous growth in equipping colonial armies brought to the development of a procedure for obtaining the nitric esters of cellulose. Nitrocellulose, also called cellulose nitrate or a mixture of nitric esters of cellulose, was discovered by the Christian Friedrich Schönbein [1], a German-Swiss chemist. He was able to increase the degree of nitration by dipping cotton in a mixture of nitric and sulfuric acids. In 1846 , C. F. Schönbein patented the discovery known as guncotton, but it did not come in use as an ingredient of gunpowder until the 1860s [2]. The reason lies in nitrocellulose instability that leads to catalytic decomposition caused by its own decomposition products. Therefore, many disastrous explosions happened during the period from 1893 to 1911 , which were caused by unstable nitrocellulose, at the elevated temperature. These accidents have led to the development of a suitable stabilizer.

Nitrocellulose in terms of basic appearance characteristics has a similar aspect as cotton, i.e., white and fibrous texture. Cellulose is a natural polymer (polysaccharide) consisting of repeating D-glucopyranose units linked by $\beta(1 \rightarrow 4)$ bonds [2] . When this molecule reacts with nitric acid, in the esterification reaction, it gives the nitrated cellulose ester polymer known as nitrocellulose or cellulose nitrate. In general, esterification reaction (1) is reversible and highly exothermic [3]:

$$
\mathrm{C}_{6} \mathrm{H}_{10} \mathrm{O}_{5}+\mathrm{xHNO}_{3} \rightarrow \mathrm{C}_{6} \mathrm{H}_{10-\mathrm{x}} \mathrm{O}_{5-\mathrm{x}}\left(\mathrm{ONO}_{2}\right)_{\mathrm{x}}+\mathrm{xH}_{2} \mathrm{O}
$$

In practice, however, the degree of nitration in macromolecule determines the solubility and flammability of final product. Also, nitrocellulose has different applications depending on their degree of nitration. Nitrocellulose with a low degree of nitration (containing approximately 10.5 to $12.5 \%$ of nitrogen) is soluble in alcohols and ethers and is employed as a film-forming agent in solvent-based paints, lacquers, varnishes, inks, etc. [4]. On the other hand, nitrocellulose with a high degree of nitration (containing more than approximately $12.5 \%$ of nitrogen) is used in gunpowder, solid rocket propellants and explosives [5].

Gunpowder, used to rapidly launch projectiles from firearms or in rocket propellants, are classified in two groups: homogeneous gunpowder and composite gunpowder. Homogeneous gunpowder, also known as colloidal or nitrocellulose-based gunpowder, formed by the process of gelatinization of nitrocellulose affected with appropriate organic solvents or gelatinizes. Composite gunpowder, in general, are plastic matrices with inorganic oxidants that do not contain nitrocellulose [6,7]. Further, homogeneous gunpowder, depending on the number of active components, can be classified in:

1. Single base gunpowder, which is mainly consisted of nitrocellulose,

2. Double base gunpowder, which consists of nitrocellulose and one more explosive substance (usually nitroglycerin or dinitroethylenglycol in a concentration from 12 to 45 $\%)$, and

3. Triple base gunpowder, composed by nitrocellulose and two other explosive substances (nitroglycerin or dinitroethylenglycol and nitroguanidine) [7].

Single base gunpowder is a colloid obtained by the process of gelatinization of low nitrated and highly nitrated cellulose with adequate solvents or mixtures of solvents. Besides nitrocellulose, single base gunpowder has a stabilizer in its

\footnotetext{
1) Military Technical Institute (VTI), Ratka Resanovića 1, 11132 Belgrade, SERBIA

Correspondence to: Magdalena Rakić, e-mail: magdalenarakic@gmail.com
} 
composition. The greatest progress in stabilization of a single base gunpowder was made in 1889 when Alfred Nobel added a special stabilizer to nitrocellulose to neutralize the catalytically active decomposition. That stabilizer is diphenylamine (DPA) [8]. DPA has the function of binding degradation products, which develop during long-term storage (e.g., $\mathrm{NO}, \mathrm{NO}_{2}, \mathrm{HNO}_{3}$ ) in order to prolong storage times [9, 11]. Otherwise, the nitric degradation produces would enhance further decomposition so that finally the powder becomes useless $[12,13]$. Examination confirmed that concentration from 1.0 to $2.5 \%$ of DPA gave the best results in concerning with stabilization of single base gunpowder. In addition to the stabilizer other binding materials in gunpowder are plasticizing agent and agent for surface treatment of grains $[14,15]$.

Chemical stability is the basic property of energetic materials (gunpowder, single base propellants and double base propellants, rocket propellants etc.) from the standpoint of safety in handling and long-term storage capacity [5]. A lot of different methods of chemical stability are already in use, but in general, results obtained from them allow the prediction of the life time as well as the selection of the adequate storage conditions. Chemical stability of gunpowder is an ability to keep chemical properties in the defined criteria as long as possible, preventing the potential self-ignition [16, 17]. Classical methods of chemical stability are based on accelerated degradation of gunpowder (and propellants), heating to precise temperatures, where the quality of energetic materials is directly dependent on evaluation and qualitative monitoring of the released gases of nitrogen oxides [18, 19]. Classical methods of chemical stability for single, double and triple base gunpowder, are: Abel test at $100^{\circ} \mathrm{C}$, Heating at $100^{\circ} \mathrm{C}$, Methyl violet method at $134.5^{\circ} \mathrm{C}$ (for single base gunpowder) and at $120^{\circ} \mathrm{C}$ (for double base gunpowder), Bergman-Jung method at $132^{\circ} \mathrm{C}$ (for single base gunpowder) and at $120^{\circ} \mathrm{C}$ (for double base gunpowder), Hansen method at $110^{\circ} \mathrm{C}$, Reactivity test at $100^{\circ} \mathrm{C}$, etc. These methods are important for interpretation of the results according to which the opinion about chemical stability can be given [20].

The aim of this research is to compare two subgroups of the Bergman-Jung method of chemical stability from the aspects of analysis of the obtained experimental results, reproducibility of the results and advantages and disadvantages of the executor for several different types of nitrocellulose gunpowder.

\section{Materials and methods}

\section{Materials}

Twelve different types of nitrocellulose gunpowder (NC), with different serial numbers, as well as five different types and series of single base tubular gunpowder (NCD) were examined. All samples were tested according to the classical method Bergman-Jung on the temperature, for single base gunpowder, at $132^{\circ} \mathrm{C}$.

\section{Preparation of samples}

Dimension and mass of samples: Single base gunpowder with dimensions of $2.5 \times 3.0 \mathrm{~mm}$ or $2.5 \times 2.5 \mathrm{~mm}$ were used as well as it is in their original shape. Larger samples were chopped into small pieces, dimensions $2.0 \times 2.5 \mathrm{~mm}$, sifted through sieves of dimensions $2.5 \times 2.0 \mathrm{~mm}$. Samples left on the $2.0 \mathrm{~mm}$ sieve were taken for testing. In the heating tubes, length $220 \pm 5 \mathrm{~mm}$ and diameter $20 \mathrm{~mm}$, was measured approximately $5.0 \pm 0.01 \mathrm{~g}$ of samples. On the heating tubes an absorption nozzle was placed.

Period of time for drain: Samples with their original shape or chopped samples were dried. The temperature of heating was $100^{\circ} \mathrm{C}$ and the drying time was 5 hours. Before putting the sample into heating tubes, they needed to cool in desiccators to the room temperature, for approximately 4 hours.

\section{METHOD: Bergman-Jung method at $132^{\circ} \mathrm{C}$}

This is a quantitative method for assessing chemical stability for nitrocellulose, all types of gunpowder and for the double base rocket propellants. The principle of this method is based on heating samples (for 5 hours) on the elevate temperature, monitoring and calculating the released nitrogen oxides. Chemical stability measure, for Bergman-Jung method, is the amount of released nitrogen oxides that are absorbed in different solvents, from which the corresponding mathematical equations quantify.

In this paper two different subgroups of classical BergmanJung method were observed.

I subgroup is based on the measuring of the volume of nitrogen oxide which was carried out by the Schulze-Timan method.

II subgroup is based on the volumetric method of titration with solvent of sodium oxide.

\section{Experimental part}

Before starting the experiment, heating tubes and absorption nozzle should be connected. The solvent for absorption of the nitrogen oxide from gunpowder is $3 \%$ of hydrogen peroxide. Also, a small sample of solid $\mathrm{MnO}_{2}$ is added into a solvent. The solvent should be carefully transferred from the absorption nozzle into the heating tube where the examined samples are placed. That apparatus was placed into a thermo block and heated at $132^{\circ} \mathrm{C}$ for 5 hours, Fig. 1 .

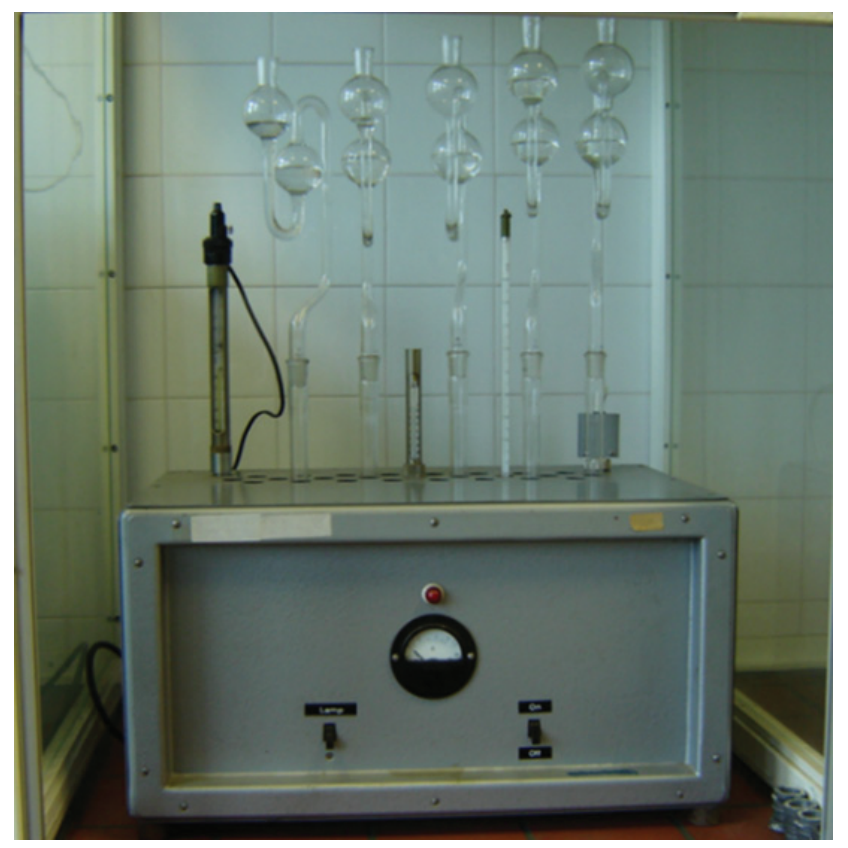

Figure 1. Apparatus for Bergman-Jung method

After heating, the apparatus was removed from the thermo block to cool down to the room temperature. The next step was to replace the solvents in the heating tubes, without bracing the connection between tubes an absorption nozzle, Fig.2. The solvents will collect the released nitrogen oxide from the examined samples of gunpowder. 


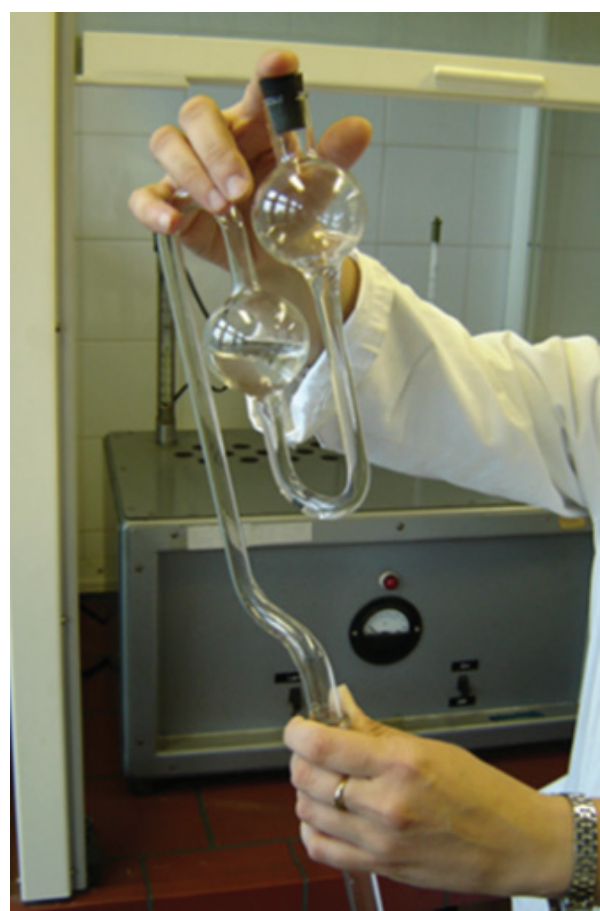

Figure 2. Replacing the solvents into the heating tube after heated at $132{ }^{\circ} \mathrm{C}$ for 5 hours

The samples with solvents were prepared according to classical analytical filtration method. Resulting solution filtrate provides the determination of nitrogen oxide by using one of subgroups of the Bergman-Jung method.

\section{I subgroup: Determination of the volume of nitrogen oxide by} the Schulze-Timan method

The chemical reaction of resulting solution filtrate was performed in an acidic medium in order to apply the SchulzeTiman method. Therefore, the resulting solution filtrate was mixed with $\mathrm{KMnO}_{4}, \mathrm{FeCl}_{2}$ and technical $\mathrm{HCl}$.

The apparatus for this method is very specific (Fig.3), and composed of: round bottom flask (a) with mixtures of resulting solution filtrate, $\mathrm{KMnO}_{4}, \mathrm{FeCl}_{2}$ and technical $\mathrm{HCl}$. The flask has the rubber stopper on the top, from which two glass tubes (b and c) of small external diameter continue. Glass tube position (b) Fig.3, is connected to the rubber hose (e) with clamps $(\mathrm{g})$, by another glass tube immersed into $\mathrm{H}_{2} \mathrm{O}(\mathrm{j})$. The Second glass tube (c) serves to drain the nitrogen oxides gases. Also, this glass tube (c) is connected to the rubber hose (f) with clamps $(\mathrm{g})$, by another bent glass tube. Bent glass tube is connected to the gas burette $(\mathrm{x})$ who is immersed into 30 percent sodium hydroxide solution (i). Mixture of the solution in flask was heated by open burner (A).

Nitrogen oxide separation reaction, from the mixture of solution, starts with heating by open burner. That was observed in an enlarged rubber hose. Relisting the clamps from the rubber hose a small volume of the $\mathrm{H}_{2} \mathrm{O}$ (approximately $10 \mathrm{~cm}^{3}$ ) was suctioned. Gases were retained in the system until the gas burette was transferred from the vessel with $\mathrm{NaOH}$ solution into vessel with $\mathrm{H}_{2} \mathrm{O}$. The gas burette with the gases was again moved to a glass cylindrical vessel filled with water, from where the concentration of nitric oxide gases was determined.

A blank test with $3 \%$ solution of $\mathrm{H}_{2} \mathrm{O}_{2}$ was performed in the same way. The volume of the blank test is calculated according to the following equation (2):

$$
V_{1}=\frac{\left(B_{0}-W\right) \cdot V \cdot 273}{760 \cdot T}
$$

Parameters in the equation (2) are:

$V_{1}$ - the volume of NO gases- blank test, $\left(\mathrm{cm}^{3}\right)$;

$B_{0}$ - the barometric pressure calculated on the standard pressure and temperature (SPT), (mbar);

$W$ - the saturation vapor pressure of water at room temperature, (mbar);

$V$ - the volume of NO gases from experiment, $\left(\mathrm{cm}^{3}\right)$;

$T$ - room temperature during experiment, $(\mathrm{K})$.

The volume of the NO in gunpowder is calculated according to the following equation (3):

$$
V_{N O+}(\text { gunpowder })=\frac{\left(B_{0}-W\right) \cdot 2 V \cdot 273}{760 \cdot T}-V_{1}
$$

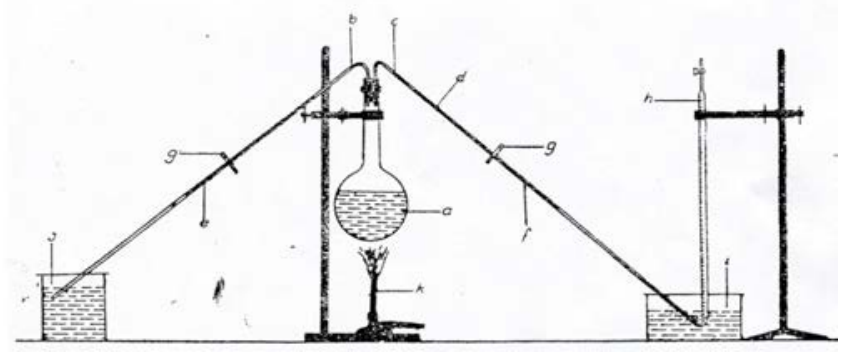

Figure 3. Determination of the concentration of nitrogen oxide by the Schulze-Timan method

Parameters in the equation (3) are:

$B_{0}$ - the barometric pressure calculated on the standard pressure and temperature (SPT), (mbar);

$\mathrm{W}$ - the saturation vapor pressure of water at room temperature, (mbar);

$V$ - the volume of NO gases from experiment, $\left(\mathrm{cm}^{3}\right)$;

$T$ - room temperature during experiment,(K);

$V_{1}$ - the volume of NO gases for blank test, $\left(\mathrm{cm}^{3}\right)$.

\section{II subgroup: Volumetric analysis method with solvent of sodium oxide}

The resulting solution filtrate which was collected as a filtrate from solvents with nitrogen oxide in it should be titrated with sodium oxide concentrations $0.05 \mathrm{~mol} / \mathrm{dm}^{3}$. The $25 \mathrm{~cm}^{3}$ of this filtrate solution was mixed with indicator phenolphthalein and titrated until it changes color from colorless to slightly pink [19].

At the same time the blank test was performed. This test was carried out with pure solution of $3 \%$ of $\mathrm{H}_{2} \mathrm{O}_{2}$ (without nitrogen oxide gases), and titration was done in the same manner as with the samples.

The consumption of $1 \mathrm{~cm}^{3}$ of sodium hydroxide solution represents the volume of $1 \mathrm{~cm}^{3}$ of nitrogen (II) oxide. The volume of the $\mathrm{NO}$ in gunpowder is calculated according to the equation (3). That result, multiplied by two, presents the volume of the relisted nitrogen oxide in the examined sample.

\section{Results and discussion}

The results of both subgroups of the Bergman-Jung method for samples NC and NCD gunpowder are shown in following tables. The results shown in Tables 1 and 2 represent an average value of three measurements given in units $\mathrm{cm}^{3}$ $\mathrm{NO} / 5 \mathrm{~g}$ of gunpowder. 
Table 1.Results for NC by the Bergman-Jung method

\begin{tabular}{|c|c|c|c|c|}
\hline \multirow[t]{3}{*}{ No } & \multicolumn{2}{|c|}{ Single base gunpowder } & \multirow{2}{*}{$\begin{array}{c}\text { I subgroup } \\
\text { V }\left(\mathrm{cm}^{3}\right)\end{array}$} & \multirow{2}{*}{$\begin{array}{c}\text { II subgroup } \\
\mathrm{V}\left(\mathrm{cm}^{3}\right)\end{array}$} \\
\hline & NC 16 & s1964 & & \\
\hline & NC 16 & s1965 & 6.84 & 8.43 \\
\hline & NC 27 & s19134 & 6.12 & 8.16 \\
\hline & NC 27 & s19135 & 5.76 & 7.85 \\
\hline & NC 26 & s19157 & 7.74 & 7.62 \\
\hline & NC 26 & s19158 & 6.48 & 6.59 \\
\hline & NC 37 & s19215 & 6.84 & 6.90 \\
\hline & NC 37 & s19216 & 5.21 & 6.37 \\
\hline & NC 36 & s1926 & 9.00 & 10.31 \\
\hline & NC 36 & s1926 & 9.18 & 10.76 \\
\hline & NC 46 & s1959 & 4.32 & 5.47 \\
\hline & NC 46 & s1961 & 5.94 & 5.34 \\
\hline & $\mathrm{NC} 42$ & s1931 & 5.22 & 6.61 \\
\hline & $\mathrm{NC} 42$ & s1931 & 5.31 & 6.77 \\
\hline & $\mathrm{NC} 43$ & s19102 & 6.61 & 7.76 \\
\hline & $\mathrm{NC} 43$ & s19102 & 6.48 & 7.40 \\
\hline & $\mathrm{NC} 44$ & s1962 & 7.56 & 7.35 \\
\hline & $\mathrm{NC} 44$ & s1962 & 7.17 & 8.16 \\
\hline & NC 122 & s1994 & 6.66 & 6.86 \\
\hline & NC 122 & s1994 & 6.38 & 7.76 \\
\hline & NC 261 & s1956 & 7.62 & 8.65 \\
\hline & NC 261 & s1956 & 7.30 & 8.75 \\
\hline & NC 281 & s19143 & 7.07 & 8.52 \\
\hline & NC 281 & s19143 & 6.84 & 8.12 \\
\hline
\end{tabular}

Table 2. Results for NCD by the Bergman-Jung method

\begin{tabular}{|c|c|c|c|c|}
\hline \multirow[t]{3}{*}{ No } & \multicolumn{2}{|c|}{ Single base tubular gunpowder } & \multirow{2}{*}{$\begin{array}{c}\begin{array}{c}\text { I subgroup } \\
\text { V (cm3) }\end{array} \\
8.10\end{array}$} & \multirow{2}{*}{$\begin{array}{c}\begin{array}{c}\text { II subgroup } \\
\text { V }(\mathrm{cm} 3)\end{array} \\
9.15\end{array}$} \\
\hline & NCD 02 & s19167 & & \\
\hline & NCD 02 & s19168 & 8.10 & 9.18 \\
\hline & NCD 06 & s19272 & 7.55 & 8.92 \\
\hline & NCD 06 & s19273 & 6.99 & 8.51 \\
\hline & NCD 02R & s19164 & 7.92 & 8.97 \\
\hline & NCD 02R & s19165 & 7.92 & 8.83 \\
\hline & NCD 22 & s1938 & 5.10 & 7.26 \\
\hline & NCD 22 & s1938 & 6.30 & 7.50 \\
\hline & NCD 27 & s1955 & 6.55 & 8.79 \\
\hline & NCD 27 & s1955 & 6.30 & 7.89 \\
\hline
\end{tabular}

Standard for chemical stability by using the Bergan-Jung method allows $11 \mathrm{~cm}^{3} \mathrm{NO} / 5 \mathrm{~g}$ of gunpowder as a maximum volume of nitrogen oxide, for NC and NCD gunpowder. All the obtained results of examined samples shown in Table ., for both subgroups, are within the criteria.

It was detected that the differences between the same NC samples for the results presented in subgroup I, were bigger than expected. Therefore, the difference of approximately $1 \mathrm{~cm}^{3}$ $\mathrm{NO} / 5 \mathrm{~g}$ of gunpowder between samples of the same type of $\mathrm{NC}$ gunpowder in addition to several series, represented a problem. Main problem lies in the Schulze-Timan method, more precisely in the process of transferring the gas burette from the vessel with $\mathrm{NaOH}$ solution into the vessel with $\mathrm{H}_{2} \mathrm{O}$. During that procedure the gas burette comes in contact with air which contains, among other gases, approximately 78 percent of nitrogen and 21 percent of oxygen. A large percentage of those two gases affects the increased of NO gases calculated according to the equations (1) and (2). However, this deviation can be a major problem with samples whose NO gases value are obtained at the upper limit or above the limit from the aspect of chemical stability. Namely, such samples will be treated as chemically unstable and will no longer be usable in ammunition.
On the other hand, analyzing the results for the subgroup II, it is detected that they are slightly increased compared to the results obtained from the subgroup I, Table 1. Since the resulting solution filtrate, with gases of nitrogen oxide in it, was taken directly for the titration method, the losses of NO gases were minimized. This directly indicates an increase in the value compared to the results collected for the subgroup I. Also, it can be noticed that the agreement in the results, within the same group of $\mathrm{NC}$ samples, is better since the deviation is up to 0.5 $\mathrm{cm}^{3} \mathrm{NO} / 5 \mathrm{~g}$ of gunpowder. However, this is not particularly surprising given the fact that the precise volumetric method provides more reliable and reproductive results.

The same trend was observed in NCD gunpowder samples whose results are shown in Table 2. Namelya better correspondence has been noticed between samples in the same group of NCD gunpowder. Although it was detected that the value of NO gases is still lower for subgroup I compared to the subgroup II. However, in this case the deviation within the same type of NCD gunpowder is still the same and it is $0.5 \mathrm{~cm}^{3} \mathrm{NO} / 5 \mathrm{~g}$ of gunpowder which confirmed validity and reproducibility of the II subgroup.

\section{Conclusion}

This paper presents comparative results for two subgroups of the classical Bergman-Jung method for determining the chemical stability of gunpowder.

Those subgroups have the same procedure of sample preparation part which is based on heating samples (for 5 hours) at the elevated temperature with special absorption nozzle. The next steps included collection and calculation of the released gases of nitrogen oxides. Depending on the type of the selected subgroup, the collection of NO gases is significantly different. The first subgroup applies the SchulzeTiman method, which includes special laboratory equipment for collecting the NO gases. The second subgroup uses the volumetric titration with solvent of sodium oxide.

Nevertheless, these two subgroups within the classical Bergman-Jung method have certain advantages and disadvantages. The greatest advantage of II subgroup is getting a large number of results in a short period of time, in relation to the subgroup I. Also, the subgroup II achieves better validity, reproducibility and accuracy of results compared to the subgroup I.

On the other hand, the subgroup I advantage is in the the value of calculated $\mathrm{NO}$ gases which are lower than the value in the subgroup II. At the same time this advantage may be the greatest disadvantage for subgroup II. The complexity of the Schulze-Timan method is that it requires extremely extensive experience in working, especially during the process of transferring the gas burette from the vessel with $\mathrm{NaOH}$ solution into vessel with $\mathrm{H}_{2} \mathrm{O}$. Accordingly, the transfer procedure should be performed carefully and correctly to minimize the absorption of gases from the air.

However, according to the standard, examined NC gunpowder are considered as chemically stable by using both subgroup of the classical Bergman-Jung method. Positive stability assessment for NCD gunpowder is also confirmed by both subgroups.

To sum up, the results shown in this paper only testify the fact that the assessment of the chemical stability by using two subgroups of the classical Bergman-Jung method is a complex process. Moreover, it is necessary to take all safety measures at work, but in addition, unforeseen situations may occur due to the examination with gases and an open burner. Besides, the interpretation of the results should be done carefully and precisely. 


\section{Acknowledgement}

The authors thank to the Ministry of Education, Science and Technological Development of the Republic of Serbia for the support of the research through Contract No. 451-039/2021-14/200325.

\section{References}

[1] BRITANNICA: The Editors of Encyclopaedia. Christian Friedrich Schönbein: Additional Information, https://www.britannica.com/biography/Christian-FriedrichSchonbein/additional-info\#history

[2] BRITANNICA: The Editors of Encyclopedia., Nitrocellulose, Encyclopedia Britannica, 2018

https://www.britannica.com/science/nitrocellulose. Accessed 15 June 2021.

[3] PHILLIPS,W.R., ORLICK,A.CH., STEINBERGER,R.: The Kinetics of the Thermal Decomposition of Nitrocellulose, J. Phys. Chem. 1955, 59, 10, pp. 1034-1039

[4] SELWITZ,C.: Cellulose nitrate in conservation; ISBN: 0-89236-0984; The Getty Conservation Institute: USA, 1998; pp. 1-67

[5] FIDANOVSKI,B., DIMIĆ,M., MILOJKOVIĆ,A., RODIĆ,V.: Determination of chemical stability of propellants using the vacuum stability test method, Scientific Technical Review, 2016, Vol.66, No.1, pp. $18-22$

[6] WAYNE,E.L.: The Gunpowder Age: China, Military Innovation, and the Rise of the West in World History, written by Tonio Andrade, Journal of Chinese Military History, 2017, 6, 1, pp. 115-130

[7] The age of gunpowder an era of technological, tactical, strategic, and leadership innovations, 5, Emory Endeavors in History 2013

[8] BERGMAN,Y.: Alfred Nobel, aniline and diphenylamine, Journal article, 2011, 17, pp. 57-67.

[9] BERGENS,A., DANIELSSON,R.: Decomposition of diphenylamine in nitrocellulose-based propellants, 1995, Talanta, 42, pp. 171-183.

[10] LINDBLOM,T., LAGERKVIST,P.SWENSSON: Comparasion and Evaluation of Modern Analytical Methods used for stability testing of a Single base Propellant, Proc. Symp.Chem.Probl.Connect. Stabil.
Explos. Smygehamn, 1985, 7, pp. 247-270.

[11] LINDBLOM,T.: Reactions In Stabilizer And Between Stabilizer And Nitrocellullose Propellants, Explos., Pyrotech., 2002, 27, pp. 197-208.

[12] ESPINOZA,E.O.: Diphenylamine and its nitrate derivatives: presence and occurrence in gunpowder and in gunshot residues, Ph.D. thesis, University of California, Berkeley, USA, 1988

[13] ESPINOZA,E.O., THORNTON,J.I.: Characterization of the gunpowder by means of the diphenylamine stabilizer and its nitrated derivatives, Anal Chem Acta, 1994, 288, pp. 57-69.

[14] DIMIĆ,M., JELISAVAC,LJ., KARIŠIK,N., BAJRAMOVIĆ,D.: Korelacija Ocene Hemijske Stabilnosti ubrzano starenih uzoraka dvobaznih raketnih goriva praćenjem potrošnje stabilizatora $i$ klasičnim metodama, 4. International scientific conference on defensive technologies - OTEX 2007, Belgrade 2007.

[15] DIMIĆ,M., JELISAVAC,LJ., KARIŠIK,N., BAJRAMOVIĆ,D.: Correlation of chemical stability assessment of accelerated aged double-base propellants using stabilizer deplation and conventional methods, International scientific conference on defensive technologies OTEX 2011, Belgrade 2011.

[16] VOGELSANGER,B.: Chemical Stability, Compatibility and Shelf Life of Explosives, Chimia, 2004, 58, № 6, pp. 401-408.

[17] BOHN,M.A.: Nc-Based Energetic Materials Stability, Decomposition And Ageing, Presentation on the meeting Nitrocellulose supply, Ageing and Characterization, Aldermaston, England, 2007

[18] DRUET,L., ASSELIN,M.: A Review of Stability Test Methods for Gun and Mortar Propellants, II: Stability testing and Surveillance, Journ. of Energ., 1988, Mater. 6, pp. 215-254.

[19] ROMANHOLO,P.V., CARRILHO,V.E.: Comprehensive Analytical Chemistry, Paper Based Sensors, 2020

[20] DIMIĆ,M., FIDANOVSKI,B., MILOJKOVIĆ,A., KRSTOVIĆ,M., JELISAVAC,LJ.: Influence of the ballistic modifier in double base rocket propellants on the chemical stability, 9th International scientific conference on defensive technologies OTEH 2020, Belgrade, 15-16 October 2020, pp. 172-176.

Received: 18.06.2021. Accepted: 16.08.2021.

\title{
Klasične metode hemijske stabnilnosti - komparativna analiza za barute
}

\begin{abstract}
Glavna komponenta baruta je nitroceluloza. Da bi se usporio katalitički proces razgradnje, dominirajući stabilizator difenilamin se koristi kod jednobaznih baruta, kao i kod pogonskih punjena. Sa druge strane, stabilizator se vremenom troši, što takođe utiče na promenu hemijske stabilnosti energetskih materijala. Jedna od klasičnih metoda za određivanje hemijske stabilnosti je Bergman-Jungova metoda. Ova metoda ima dve podgrupe čije su uporedne analize za dvanaest NC i pet NCD baruta predstavljene u ovom radu. Naime, obe podgrupe se zasnivaju na proračunu zapremine gasova azotnog oksida, ali se razlikuju po načinu prikupljanja i određivanja oslobođenih gasova.
\end{abstract}

Ključne reči: hemijska stabilnost, jednobazni barut, metoda Bergman-Jung, Šulce-Timanova metoda, Volumetrijska metoda. 